\title{
PENGARUH KUALITAS PRODUK, HARGA DAN CITRA MEREK TERHADAP KEPUTUSAN PEMBELIAN ULANG IKAN ASIN DI KOTA PADANG
}

\section{The Effect of Product Quality, Price and Brand Image Toward the Decision to Repurchase "Ikan Asin" In Padang City}

\author{
*Imtihan ${ }^{1}$ dan Irwandi ${ }^{2}$ \\ ${ }^{1}$ Fakultas Sosial dan Humaniora, Universitas Nahdlatul Ulama Sumatera Barat \\ JI. S. Parman No. 119 Ulak Karang Kota Padang Sumatera Barat Indonesia. \\ ${ }^{2}$ Fakultas Sains, Universitas Nahdlatul Ulama Sumatera Barat \\ JI. Jl. S. Parman No. 119 Ulak Karang Kota Padang Sumatera Barat Indonesia. \\ Diterima tanggal: 1 Agustus 2020 Diterima setelah perbaikan: 8 Juni 2021 \\ Disetujui terbit: 25 Juni 2021
}

\begin{abstract}
ABSTRAK
"Ikan asin" merupakan makanan paling popular di Kota Padang. Penelitian ini bertujuan untuk menganalisis pengaruh kualitas produk, harga dan citra merek terhadap keputusan pembelian ulang "Ikan Asin" di Kota Padang. Jenis penelitian ini adalah penelitian kausatif yang melihat pengaruh kualitas produk, harga dan citra merek terhadap keputusan pembelian ulang. Penentuan jumlah sampel menggunakan teknik purposive sampling. Jumlah sampel yang di ambil adalah 100 responden. Teknik analisis data yang digunakan adalah analisis jalur (Path Analysis) untuk membuktikan besarnya pengaruh kualitas produk, harga dan citra merek terhadap keputusan pembelian ulang "Ikan Asin" di Kota Padang. Penelitian ini membuktikan bahwa kualitas produk, harga dan citra merek berpengaruh signifikan terhadap Keputusan Pembelian Ulang Ikan Asin di Kota Padang. Hal ini dapat digunakan sebagai acuan bagi para produsen ikan asin dalam upaya pengembangan produk dan meningkatkan hasil penjualan kedepannya.
\end{abstract}

Kata Kunci: citra merek; harga; kualitas produk; keputusan pembelian ulang

\begin{abstract}
ABSTRAK
"Ikan asin" is the most popular food of people in Padang city. This study aims to analyze the effect of product quality, price and brand image toward the decision to repurchase "ikan asin" in Padang city. This type of research is causative research to investigate the influence of product quality, price, and brand image on repurchase decision. The samples were determined using purposive sampling technique. The number of samples were 100 respondents. Data analysis technique is path analysis to identify the effect of product quality, price and brand image toward the decision to repurchase "ikan asin" in Padang city. The research showed that product quality, price and brand image have significant effect toward the decision to repurchase "ikan asin" in padang city. This research proved that product quality, price and brand image took effect siqnificantly towards salted fish purchase decision in Padang City.
\end{abstract}

Keywords: brand image; price; product quality; repurchase decision

\section{PENDAHULUAN}

Ikan asin merupakan salah satu jenis dari Usaha Mikro Kecil dan Menengah (UMKM) Kota Padang yang memiliki konsumen cukup banyak. Hal ini dapat dilihat dari jumlah penggunaan garam oleh industri rumah tangga dimana penggunaan garam oleh masyarakat Kota Padang mencapai 3.000 ton dal satu tahun. Lebih lanjut salah seorang pengelola ikan asin, Darma 59 tahun dalam republika.co.id mengemukakan bahwa naiknya harga garam mengakibatkan turunnya jumlah produksi hingga $50 \%$. Lebih lanjut di katakan bahwa dalam satu hari produsen mampu memproduksi hingga 100 kilogram ikan asin jenis teri, namun semenjak kenaikan harga garam produksi hanya mencapai 50 kilogram. Media cetak Harian Haluan mengemukakan bahwa sebelumnya ikan asin merupakan produk andalan warga Kota Padang yang memiliki konsumen yang cukup banyak akan tetapi beriringnya waktu 
dan harga garam yang semakin meningkat serta semakin banyaknya pesaing yang menawarkan berbagai produk yang beranekaragam dengan harga yang terjangkau menyebabkan konsumen ikan asin mengalami penurunan.

Hal ini berarti besarnya minat masyarakat Kota Padang untuk mengkonsumsi ikan asin tidak terlepas dari kenyamanan dan kepuasan yang dirasakan konsumen dalam mengkonsumsi ikan asin sehingga mendorong munculnya kepercayaan konsumen terhadap suatu produk dan berdampak terhadap keputusan pembelian berulang. Yusra \& Efendi (2010) mengemukakan bahwa salah satu kelemahan ikan sebagai bahan makanan ialah sifatnya yang mudah busuk setelah ditangkap dan mati sehingga perlu pengolahan yang cepat agar ikan tetap dalam kondisi yang layak dikonsumsi oleh konsumen. Dengan proporsi ikan yang dipasarkan dalam keadaan segar sebesar $67,1 \%$ dan di pasarkan dalam bentuk produk ikan asin kering atau asin sebesar 13,24\%. Lebih lanjut Yusra (2017) bahwa mengemukakan bahwa untuk memperpanjang mutu ikan olahan, pengolah menambahkan bahan pengawet berbaha lain seperti boraks dan formalin. Berdasarkan fenomena tersebut maka agar tercipta kepercayaan konsumen maka Dinas Koperasi dan UMKM Kota Padang melakukan pengawasan terhadap sistem jual beli di Kota Padang, terutama yang terkait dengan produk yang ditawarkan kepada konsumen. Hal ini juga mendapatkan dukungan dari UndangUndang No.8 Bab I Pasal I Tahun 1999 tentang perlindungan konsumen yaitu menjelaskan bahwa dengan segala upaya pemerintah menjamin adanya kepastian hukum untuk memberi perlindungan kepada konsumen. Tujuannya, yaitu agar produsen dan pedangan ikan asin di Kota Padang berusaha memberikan yang terbaik untuk konsumen.

Kepastian hukum yang telah diberikan oleh pemerintah hal ini berarti pemerintah telah berupaya untuk memberikan yang terbaik kepada konsumen. Selanjutnya, sejalan dengan perkembangan IImu Pengetahuan dan Teknologi (IPTEK), timbulnya berbagai barang substitusi, pesaing pasar yang semakin meningkat dan keterbatasan SDM yang terbatas, hal ini menimbulkan perilaku baru yang kurang memperhatikan hak konsumen. Realita menunjukkan bahwa terdapat beberapa produsen yang berbuat curang dalam pengolahan produk yang di tawarkan Seperti penggunaan bahan zat kimia berupa formalin dalam pengawetan ikan asin sehingga secara tidak langsung menyebabkan konsumen sering tertipu dalam melakukan pembelian. Dimana pada tahap pertama pembelian masyarakat merasa senang namun pada tahap berikutnya masyarakat enggan untuk melakukan pembelian ikan asin karena merasa kecewa dengan ikan asin yang telah mereka beli pada tahap sebelumnya. Berdasarkan hal tersebut banyak konsumen yang sadar bahwa dengan penambahan formalin dapat mengahasilkan produk dengan penampakan yang lebih bagus namun di lihat dari aspek keamanan penggunaan formalin menyebabkan kualitas ikan asin yang menurun yang akan berdampak terhadap kesehatan konsumen. Akibatnya konsumen sadar akan bahaya formalin sehingga konsumen enggan untuk membeli kembali dan cenderung untuk beralih keproduk lain yang sejenis.

Berdasarkan informasi yang penulis peroleh dari media cetak Harian Haluan, Safaruddin (2018) mengemukakan bahwa sebelumnya ikan asin merupakan produk andalan warga Kota Padang karena memiliki kualitas terbaik yaitu pengolahannya tanpa menggunakan pengawet atau formalin sehingga memiliki konsumen yang cukup banyak. Akan tetapi beriringnya waktu dengan munculnya berbagai produk substitusi atau pengganti ikan asin yang sejenis dan harga garam yang semakin meningkat hal ini menjadi penyebab beberapa produsen ikan asin berpikir untuk tidak rugi dan bertindak secara curang dengan melakukan penambahan formalin kedalam pengolahan ikan asin. Selanjutnya, dengan semakin banyaknya pesaing yang menawarkan berbagai produk pengganti ikan asin (barang substitusi) yang beranekaragam dengan harga yang terjangkau maka hal ini menyebabkan konsumen ikan asin mengalami penurunan. Hal ini berarti, tidak adanya pembelian ulang yang dilakukan oleh konsumen karena ikan asin yang tergolong kepada produk subtitusi atau pengganti telah di tukar dengan produk lain yang sejenis seperti; ikan laut, ikan tawar, ayam, daging, ataupun telur.

Kotler \& Keller (2012) mengemukakan bahwa keputusan pembelian berulang adalah tindakan atau action yang dilakukan konsumen untuk pembelian kembali terhadap produk yang telah digunakan sebelumnya. Berdasarkan hal tersebut maka menurut asumsi penulis terjadinya pembelian ulang ikan asin dapat dipengaruhi oleh berbagai faktor, tiga faktor utama yang sangat mempengaruhi: Pertama kualitas produk, yaitu produk yang memiliki kualitas yang baik akan menciptakan keunggulan atau daya tarik yang akan berdampak terhadap brand image produk 
tersebut. Kedua harga, karena harga dari suatu produk berhubungan dengan anggaran yang dimiliki konsumen dengan asumsi harga barang lain di anggap tetap (ceteris paribus). Artinya, konsumen akan membeli ikan asin apabila sesuai dengan anggaran yang dimilikinya selama barang pengganti lainnya (barang substitusi) masih berada pada harga yang tetap. Ketiga citra merek, yaitu produk yang memiliki merek yang bagus (brand image) akan menciptakan persepsi tersendiri yang berada di dalam ingatan konsumen.

Berdasarkan fenomena dan fakta yang terdapat pada media cetak Haluan dan obeservasi awal yang dilakukan maka dengan menganalisis pengaruh kualitas produk, harga dan citra merek ikan asin terhadap keputusan pembelian berulang maka hal tersebut akan memberikan informasi terhadap pedagang ikan asin selaku produsen ataupun distributor di Kota Padang mengenai kebutuhan konsumen terkait dengan produk yang di tawarkannya dan terkhusus memberikan kepastian bahwa jaminan hukum yang diberikan oleh pemerintah terhadap konsumen sudah direalisasikan oleh produsen atau distributor ikan asin secara maksimum.

\section{METODOLOGI}

\section{Lokasi dan Waktu Penelitian}

Penelitian ini dilaksanakan di Kota Padang yang terdiri atas sebelas Kecamatan, yaitu: (1) Kecamatan Padang Utara, (2) Kecamatan Padang Timur, (3) Kecamatan Padang Barat, (4) Kecamatan Padang Selatan, (5) Kecamatan Lubuk Kilangan, (6) Kecamatan Lubuk Begalung, (7) Kecamatan Pauh, (8) Kecamatan Kuranji, (9) Kecamatan Nanggalo, (10) Kecamatan Koto Tangah dan (11) Kecamatan Bungus Teluk Kabung. Selanjutnya pelaksanaan penelitian dimulai pada bulan Maret hingga berakhir pada bulan September 2019.

\section{Jenis dan Metode Pengambilan Data}

Penelitian ini termasuk ke dalam jenis penelitian kausatif yang bertujuan untuk menganalisis hubungan yang terjadi antara variabel-variabel. Variabel yang diteliti dalam penelitian ini adalah Pertama; variabel kualitas produk (X1) dengan indikator daya tahan produk, kualitas yang dirasakan dan keindahan tampilan , variabel harga (X2) dengan indikator; yaitu keterjangkauan harga, daya saing harga dan kesesuaian harga dengan manfaat produk dan variabel citra merek (X3) dengan indikator, yaitu atribut, nilai dan kepribadian konsumen dengan variabel terikat yaitu keputusan pembelian ulang (Y) dengan indikator; mencari informasi, keputusan pembelian dan perilaku setelah pembelian. Populasi dalam penelitian ini adalah semua konsumen Kota Padang yang mengkonsumsi ikan asin setiap bulannya. Dalam hal ini jumlah populasi adalah 300 konsumen. Teknik pengambilan sampel adalah menggunakan metode purposive sampling yang didasarkan pada kriteria khusus yang terdapat pada populasi. Jumlah sampel yang diambil adalah 100 responden. Metode pengumpulan data dalam penelitian ini dilakukan dengan cara wawancara dengan menggunakan bantuan kuesioner (angket) terstruktur. Penyusunan kuesioner berdasarkan pada skala Likert yang telah dimodifikasi yang sifatnya positif dan negatif. Untuk mendapatkan data yang baik maka sebelum kuesioner dibagikan kepada kelas sampel maka terlebih dahulu dilakukan uji coba instrumen untuk melihat tingkat validitas dan reliabilitas. Berdasarkan uji validitas diperoleh hasil bahwa dari 60 butir item terdapat 57 butir item dinyatakan tidak valid dan 3 butir item dinyatakan tidak valid dan item. Selanjutnya untuk tingkat reliabilitas diperoleh nilai Cronbach Coefficient Alpha variabel kualitas produk sebesar 0.891 , variabel harga 0.880 dan variabel citra merek sebesar 0.875 dan berarti memiliki tingkat reliabilitas tinggi.

\section{Metode Analisis}

Teknik analisis data yang digunakan adalah analisis jalur (path analysis). Idris (2012) mengemukakan bahwa Analisis ini digunakan untuk menganalisis pola hubungan kausal antar variabel, dengan tujuan untuk mengetahui pengaruh langsung dan tidak langsung secara bersama-sama maupun secara parsial variabel eksogen terhadap variabel endogen penelitian. Artinya dengan menganalisis pengaruh langsung dan tidak langsung kualitas produk, harga dan citra merek terhadap pembelian berulang maka penulis dapat mengetahui besarnya kontribusi yang diberikan oleh masing-masing variabel bebas (kualitas produk, harga dan citra merek) terhadap variabel terikat (keputusan pembelian ulang). Lebih lanjut dijelaskan bahwa teknik analisis jalur ini telah banyak dipergunakan untuk memprediksi perilaku beli dari seorang konsumen.

Selanjutnya, pada model ini peneliti mencoba membuktikan pengaruh kualitas produk dan harga terhadap keputusan pembelian ulang dengan citra merek sebagai variabel perantara: 


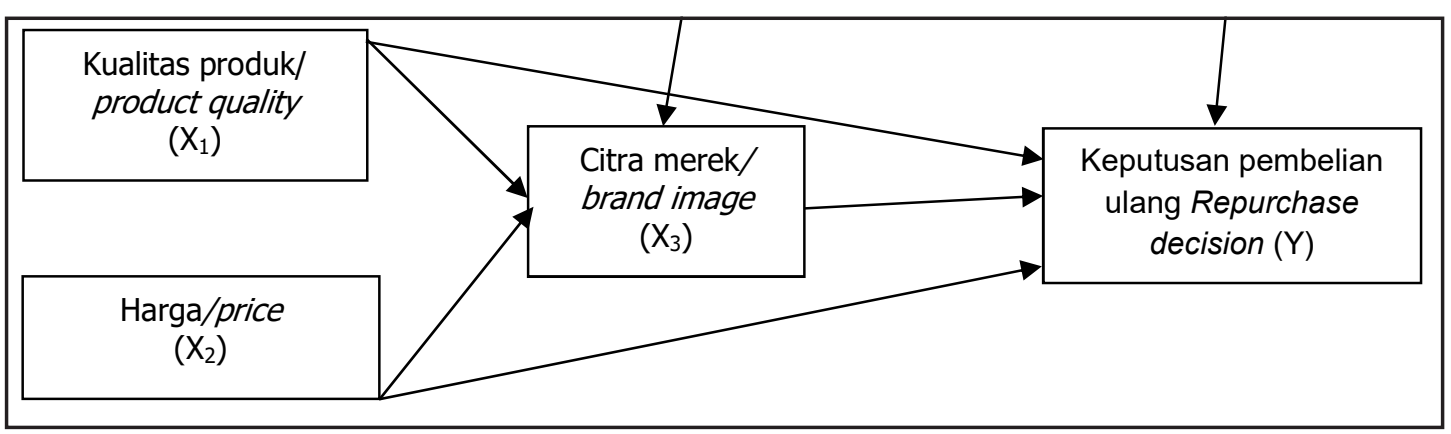

Gambar 1. Diagram Kerangka Konseptual Penelitian.

Figure 1. Research Conceptual Framework Diagram.

Selanjutnya menurut Idris (2012) secara manual langkah-langkah yang harus ditempuh dalam analisis jalur adalah sebagai berikut:

1. Menentukan koefisien jalur $\left(P_{Y} x_{i}\right)$ dengan rumus:/ determine the path coefficient $\left(P_{Y} x_{i}\right)$ the formula:

$$
\text { PYXi }=\text { byxi } \sqrt{\frac{\sum_{h=1}^{n} X_{i h}^{2}}{\sum_{h=1}^{n} Y_{h}^{2}}}: \mathrm{i}=1,2
$$

Keterangan/Remaks:

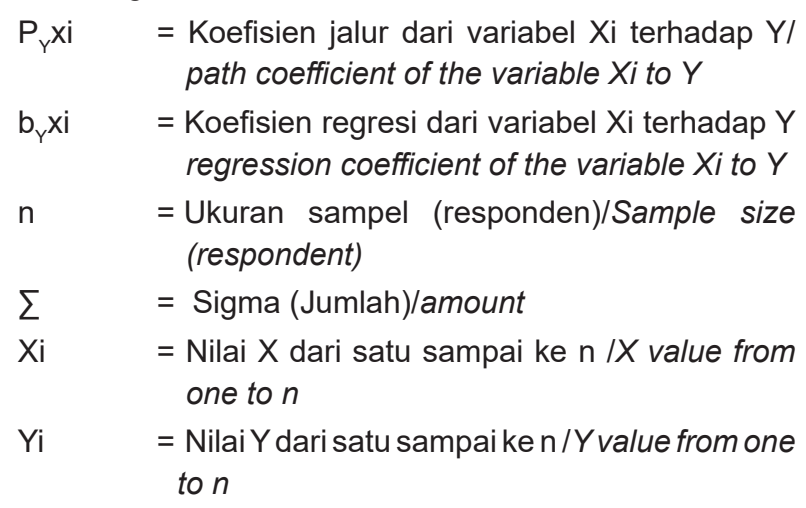

$\mathrm{i}=1,2 \mathrm{dst}=$ Variabel Penelitian/Research variable

2. Menentukan pengaruh variabel lain $\left(P_{Y \varepsilon}\right)$ dengan rumus:/determine the effect of other variables $\left(P_{\text {YE }}\right)$ the formula:

$$
P_{Y \varepsilon}=\sqrt{1-R_{Y X 1 X 2 X 3}^{2}}
$$

\section{Keterangan/Remaks:}

$$
\begin{aligned}
P_{Y \varepsilon} & =\begin{array}{l}
\text { Pengaruh variabel lain dalam penelitian/Effect } \\
\text { of other variables in the research }
\end{array} \\
= & \text { Konstanta/constant } \\
\mathrm{R}^{2}{ }_{Y \times 1 \times 2 \times 3}= & \text { Koefisien yang menyatakan determinan total } \\
& \text { dari semua variabel penyebab (variabel bebas } \\
& \text { terhadap variabel akibat (variabel terikat } \\
& \text { which coefficient states the total determinant } \\
& \text { of all causal variables (independent variables) } \\
& \text { with respect to the effect variable (dependent } \\
& \text { variable) }
\end{aligned}
$$

3. Melakukan uji $F$ dan uji $t$ dengan dasar pengambilan keputusan adalah sebagai berikut:/ peform the $F$ test and $t$ test with the basis of decision making are is follows:

a. Uji F (uji simultan)

1) Jika probabilitas $F_{\text {hitung }}<0,05$ maka Ho ditolak (koefisien regresi signifikan)/ If probability $F_{\text {hitung }}<0,05$ then is rejected $\mathrm{Ho}$ (coefficient regression significant)

2) Jika probabilitas $F_{\text {hitung }}>0,05$ maka Ho diterima (koefisien regresi tidak signifikan)/ If probability $F_{\text {nitung }}>0,05$ then is accepted Ho (coefficient regression not significant)

b. Uji t (uji parsial)

1) Jika probabilitas $t_{\text {hitung }}<0,05$ maka Ho ditolak (koefisien regresi signifikan)/ If probability $t_{\text {hitung }}<0,05$ then is rejected $\mathrm{Ho}$ (coefficient regression significant)

2) Jika probabilitas $t_{\text {hitung }}>0,05$ maka Ho diterima (koefisien regresi tidak signifikan)/ If probability $t_{\text {hitung }}>0,05$ then is accepted Ho (coefficient regression not significant)

4. Menentukan pengaruh dari satu variabel ke variabel lain (secara langsung maupun tidak langsung)/determine the effect of one variable to another (directly or indirectly)

5. Menentukan interpretasi tentang kontribusi setiap variabel terhadap variabel lain (secara langsung maupun tidak langsung)/make interpretation of the contribution of each variable to other variables (directly or indirectly)

\section{HASIL DAN PEMBAHASAN}

\section{Karakteristik Konsumen}

Karakteristik konsumen dalam penelitian ini adalah konsumen yang berdomisili di Kota Padang yang terdiri atas kecamatan, yaitu; (1) padang 
barat dengan 9 responden, (2) padang timur dengan 9 responden, (3) padang selatan dengan 9 responden, (4) koto tangah dengan Sembilan responden, (5) lubuk begalung dengan 9 responden, (6) pauh dengan 9 responden, (7) lubuk kilangan dengan 9 responden, (8) kuranji dengan 9 responden, (9) padang utara dengan 9 responden, (10) nanggalo dengan 10 responden dan (11) bungus teluk kabung dengan 9 responden. Selanjutnya responden dikelompokkan berdasarkan usia, pekerjaan, dan pendapatan per bulan.

Tabel 1. Karakteristik Konsumen Berdasarkan Usia. Table 1. Consumer Characteristics Based on Age.

\begin{tabular}{ccc}
\hline Usia/age & $\begin{array}{c}\text { Populasi/ } \\
\text { Population }\end{array}$ & $\begin{array}{c}\text { Persentase (\%)/ } \\
\text { Percentage (\%) }\end{array}$ \\
\hline $18-27$ & 17 & $17 \%$ \\
$28-37$ & 24 & $24 \%$ \\
$38-47$ & 39 & $39 \%$ \\
$48-57$ & 20 & $20 \%$ \\
Total & $\mathbf{1 0 0}$ & $\mathbf{1 0 0 \%}$ \\
\hline
\end{tabular}

Tabel 2. Karakteristik Responden Berdasarkan Pekerjaan.

Table 2. Consumer Characteristics Based on Occupation.

\begin{tabular}{ccc}
\hline $\begin{array}{c}\text { Pendapatan Per Bulan/ } \\
\text { Monthly Income } \\
\text { (Rp/IDR) }\end{array}$ & $\begin{array}{c}\text { Populasi/ } \\
\text { Population }\end{array}$ & $\begin{array}{c}\text { Persentase/ } \\
\text { Percentage } \\
\text { (\%) }\end{array}$ \\
\hline$<1,000,000$ & 26 & $26 \%$ \\
$1,000,000-2,000,000$ & 21 & $21 \%$ \\
$2,000,000-3,000,000$ & 28 & $28 \%$ \\
$3,000,000-4,000,000$ & 11 & $11 \%$ \\
$>4,000,000$ & 14 & $14 \%$ \\
Total & 100 & $\mathbf{1 0 0 \%}$ \\
\hline
\end{tabular}

Tabel 3. Karakteristik Responden Berdasarkan Pendapatan Perbulan.

Table 3. Consumer Characteristics Based on Monthly Income.

\begin{tabular}{ccc}
\hline $\begin{array}{c}\text { Pendapatan Per Bulan/ } \\
\text { Monthly Income }\end{array}$ & $\begin{array}{c}\text { Populasi// } \\
\text { Population }\end{array}$ & $\begin{array}{c}\text { Persentase/ } \\
\text { Percentage } \\
\text { (\%) }\end{array}$ \\
\hline$<1,000,000$ & 8 & $8 \%$ \\
$1,000,000-2,000,000$ & 19 & $19 \%$ \\
$2,000,000-3,000,000$ & 34 & $34 \%$ \\
$3,000,000-4,000,000$ & 26 & $26 \%$ \\
$>4,000,000$ & 13 & $13 \%$ \\
Total & $\mathbf{1 0 0}$ & $\mathbf{1 0 0 \%}$ \\
\hline
\end{tabular}

Berdasarkan Tabel 1, 2 dan 3 di atas dapat dilihat bahwa konsumen di Kota Padang yang mengkonsumsi ikan asin didominasi oleh masyarakat berusia 38-47 tahun dengan persentase sebesar $39 \%$. Selanjutnya apabila dilihat dari jenis pekerjaan, konsumen ikan asin di Kota Padang didominasi oleh masyarakat yang memiliki pekerjaan sebagai wiraswasta dengan persentase sebesar $28 \%$.Selanjutnya dilihat dari segi pendapatan per bulan, konsumen ikan asin Kota Padang didominasi oleh masyarakat yang memiliki pendapatan Rp2.000.000 sampai Rp3.000.000 per bulan dengan persentase sebesar $34 \%$.

\section{Analisis Deskriptif Variabel Penelitian}

Bagian ini menjelaskan deskripsi masing-masing variabel penelitian. Penyajian data masing-masing variabel dilakukan dalam bentuk distribusi frekuensi dimana masingmasing responden memberikan penilaian sesuai dengan pendapat masing-masing. Selanjutnya deskripsi dari setiap variabel disesuaikan dengan indicator yang telah ditetapkan dalam penelitian. Adapun deskripsi lebih lanjut untuk masingmasing variabel penelitian adalah sebagai berikut.

Tabel 4. Deskriptif Variabel Keputusan Pembelian Ulang.

Table 4. Descriptive Variable Repurchase Decisions.

\begin{tabular}{lccc}
\hline \multicolumn{1}{c}{$\begin{array}{c}\text { Indikator/ } \\
\text { Indicator }\end{array}$} & $\begin{array}{c}\text { Rerata/ } \\
\text { Mean }\end{array}$ & $\begin{array}{c}\text { Tingkat } \\
\text { Capaian } \\
\text { Responden/ } \\
\text { Achievement } \\
\text { Level of } \\
\text { Respondents }\end{array}$ & $\begin{array}{l}\text { Keterangan/ } \\
\text { Information }\end{array}$ \\
\hline $\begin{array}{l}\text { Mencari } \\
\text { Informasi/ }\end{array}$ & 3.92 & 78.44 & Baik/Good \\
$\begin{array}{l}\text { Searching for } \\
\text { information } \\
\text { Keputusan } \\
\text { pembelian/ } \\
\text { Buying decision }\end{array}$ & 4.00 & 79.92 & Baik/Good \\
$\begin{array}{l}\text { Perilaku setelah } \\
\text { pembelian/ } \\
\text { Behavior after } \\
\text { purchase } \\
\text { Rerata/Mean }\end{array}$ & 3.83 & 76.68 & Baik/Good \\
\hline
\end{tabular}

Berdasarkan Tabel 4 dapat dilihat bahwa rata-rata Keputusan Pembelian Ulang produk ikan asin sebesar 3,92 dengan nilai TCR mencapai $78,35 \%$ dengan kualifikasi Baik, diimana nilai tertinggi diberikan oleh indikator keputusan pembelian.

Selanjutnya, pada Tabel 5 deskripsi dari variabel Kualitas Produk memiliki nilai ratarata sebesar 3,84 dengan nilai TCR sebesar 76,87 dengan kualifikasi Baik, dimana nilai tertinggi diberikan oleh indikator daya tahan produk. 
Tabel 5. Deskriptif Variabel Kualitas Produk. Table 5. Descriptive Variable Product Quality.

\begin{tabular}{|c|c|c|c|}
\hline $\begin{array}{l}\text { Indikator/ } \\
\text { Indicator }\end{array}$ & $\begin{array}{c}\text { Reratal } \\
\text { Mean }\end{array}$ & $\begin{array}{c}\text { Tingkat } \\
\text { Capaian } \\
\text { Responden/ } \\
\text { Achievement } \\
\text { Level of } \\
\text { Respondents }\end{array}$ & $\begin{array}{l}\text { Keterangan/ } \\
\text { Information }\end{array}$ \\
\hline $\begin{array}{l}\text { Daya Tahan } \\
\text { Produk/Product } \\
\text { durability }\end{array}$ & 3.90 & 77.96 & Baik/Good \\
\hline $\begin{array}{l}\text { Kualitas yang } \\
\text { di rasakan/ } \\
\text { Perceived quality }\end{array}$ & 3.81 & 76.25 & Baik/Good \\
\hline $\begin{array}{l}\text { Keindahan } \\
\text { tampilan/The } \\
\text { beauty of the look }\end{array}$ & 3.82 & 76.40 & Baik/Good \\
\hline Rerata/Mean & 3.84 & 76.87 & Baik/Good \\
\hline
\end{tabular}

Pada Tabel 6 variabel harga memiliki nilai rata-rata sebesar 3,92 dengan nilai TCR sebesar 78,39 dengan kualifikasi Baik, dimana nilai tertinggi diberikan oleh indikator keterjangkauan harga.

Tabel 6. Deskriptif Variabel Harga. Table 6. Descriptive Variable Price.

\begin{tabular}{|c|c|c|c|}
\hline $\begin{array}{l}\text { Indikator/ } \\
\text { Indicator }\end{array}$ & $\begin{array}{c}\text { Rerata/ } \\
\text { Mean }\end{array}$ & $\begin{array}{c}\text { Tingkat } \\
\text { Capaian } \\
\text { Responden/ } \\
\text { Achievement } \\
\text { Level of } \\
\text { Respondents }\end{array}$ & $\begin{array}{l}\text { Keterangan/ } \\
\text { Information }\end{array}$ \\
\hline $\begin{array}{l}\text { Keterjangkauan } \\
\text { harga/Price } \\
\text { affordability }\end{array}$ & 3.95 & 79.05 & Baik/Good \\
\hline $\begin{array}{l}\text { Daya saing } \\
\text { harga/Price } \\
\text { competitiveness }\end{array}$ & 3.92 & 78.32 & Baik/Good \\
\hline $\begin{array}{l}\text { Kesesuaian } \\
\text { harga dengan } \\
\text { manfaat produk } \\
\text { Suitability of } \\
\text { prices with } \\
\text { product benefits }\end{array}$ & 3.89 & 77.80 & Baik/Good \\
\hline Rerata/Mean & 3.92 & 78.39 & Baik/Good \\
\hline
\end{tabular}

Selanjutnya, pada Tabel 7 variabel citra merek memiliki nilai rata-rata sebesar 3,98 dengan nilai TCR sebesar 79,67 dengan kualifikasi Baik, dimana nilai tertinggi diberikan oleh indikator nilai dari sebuah produk ikan asin tersebut. Adapun rincian dari masing-masing hal tersebut dapat dilihat pada Tabel 7.

Berdasarkan deskriptif variabel keputusan pembelian ulang terlihat nilai skor rata-rata yang diberikan konsumen unutuk melakukan pembelian ulang adalah sebesar 3,92 dengan nilai persentase
Tabel 7. Deskriptif Variabel Citra Merek.

Table 7. Descriptive Variable Brand Image.

\begin{tabular}{lccl}
\hline \multicolumn{1}{c}{$\begin{array}{c}\text { Indikator/ } \\
\text { Indicator }\end{array}$} & $\begin{array}{c}\text { Rerata/ } \\
\text { Mean }\end{array}$ & $\begin{array}{c}\text { Tingkat } \\
\text { Capaian } \\
\text { Responden/ } \\
\text { Achievement } \\
\text { Level of } \\
\text { Respondents }\end{array}$ & $\begin{array}{l}\text { Keterangan/ } \\
\text { Information }\end{array}$ \\
\hline Atribut/Attribute & 4.00 & 79.90 & Baik/Good \\
$\begin{array}{l}\text { Nilai/Score } \\
\text { Kepribadian }\end{array}$ & 4.02 & 80.36 & Baik/Good \\
$\begin{array}{l}\text { konsumen/ } \\
\text { Consumer } \\
\text { personality }\end{array}$ & 3.94 & 78.76 & Baik/Good \\
Rerata/Mean & 3.98 & 79.67 & Baik/Good \\
\hline
\end{tabular}

TCR yang dihasilkan mencapai 78,35 . Sugiono (2010:78) menyatakan bahwa Tingkat Capaian Responden (TCR) merupakan suatu metode penilaian dengan cara Menyusun orang yang dinilai berdasrkan peringkatnya pada berbagai sifat yang dinilai. Selanjutnya nilai skor rata-rata yang diberikan konsumen untuk kualitas produk sebesar 3,84 dengan nilai TCR sebesar 76,87. Variabel harga terlihat nilai skor rata-rata yang diberikan konsumen sebesar 3,92 dengan nilai persentase TCR yang dihasilkan mencapai 78,39 . Selanjutnya nilai skor rata-rata yang diberikan konsumen untuk citra merek sebesar 3,98 dengan nilai persentase TCR yang dihasilkan mencapai 79,67. Berdasarkan hal tersebut semua variabel memiliki TCR pada kualifikasi baik.

\section{Analisis Induktif Variabel Penelitian (Analisis Jalur/Path Analysis)}

Untuk mengetahui pengaruh variabel eksogen terhadap variabel endogen maka analisis induktif variabel penelitian dilakukan dengan menggunakan metode analisis jalur (path analysis). dalam hal ini, penggunaan metode Analisis Jalur (path analysis) penelitian terdiri atas dua sub struktur. Selanjutnya pada masing-masing sub struktur akan di proses melalui bantuan program SPSS (Statistical Product and Service Solutions) versi 16.0 .

\section{a. Analisis Sub Struktur I}

Pada bagian sub struktur 1 membahas tentang pengaruh variabel kualitas produk (X1) dan harga (X2) terhadap variabel citra merek (X3). Adapun hasil pengolahan data pengaruh kualitas produk dan harga terhadap citra merek dapat dilihat pada Tabel 8. 
Tabel 8. Koefisien Jalur Variabel Kualitas Produk dan Harga terhadap Citra Merek.

Table 8. Path Coefficient of Product Quality and Price Variables on Brand Image.

\begin{tabular}{lcccc}
\hline \multicolumn{1}{c}{$\begin{array}{c}\text { Variabel } \\
\text { bebas/ } \\
\begin{array}{l}\text { Independent } \\
\text { Variable }\end{array}\end{array}$} & $\begin{array}{c}\text { Koefisien } \\
\text { Jalurl } \\
\text { Path } \\
\text { Coefficient }\end{array}$ & $\mathbf{t}_{\text {hitung }}$ & $\begin{array}{l}\text { Signifikan/ } \\
\text { Significant }\end{array}$ & $\begin{array}{c}\text { Alfa/ } \\
\text { Alpha }\end{array}$ \\
\hline $\begin{array}{l}\text { Kualitas } \\
\text { produk/Product } \\
\text { quality } \\
\text { Harga/Price }\end{array}$ & 0.240 & 2.067 & 0.041 & 0.05 \\
\hline
\end{tabular}

Berdasarkan Tabel 8 di atas yang diolah menggunakan Program SPSS dapat dilihat bahwa kualitas produk dan harga memiliki nilai signifikan kurang dari 0,05 yang berarti koefisien regresi dari variabel bebas (kualitas produk dan harga) memiliki pengaruh positif terhadap citra merek. Adapun bentuk hubungannya dapat dilihat pada gambar sub struktur I dapat dilihat pada Gambar 2.

\section{b. Analisis Sub struktur II}

Pada bagian sub struktur kedua bertujuan untuk mendapatkan bukti empiris pengaruh langsung antara kualitas produk (X1), harga (X2) dan citra merek (X3) terhadap keputusan pembelian ulang (Y). Adapun hasil pengujian statistik diperoleh hasil seperti pada Tabel 9.
Tabel 9. Koefisien Jalur Variabel Kualitas Produk, Harga dan Citra Merek terhadap Keputusan Pembelian Ulang.

Table 9. Path Coefficient of Product Quality, Price and Brand Image Variables on Repurchase Decision.

\begin{tabular}{lcccc}
\hline $\begin{array}{c}\text { Variabel } \\
\text { bebas/ } \\
\begin{array}{l}\text { Independent } \\
\text { Variable }\end{array}\end{array}$ & $\begin{array}{c}\text { Koefisien } \\
\text { Jalurl } \\
\text { Path } \\
\text { Coefficient }\end{array}$ & $\begin{array}{c}\mathbf{t}_{\text {hitung }} \\
\mathbf{t}_{\text {count }}\end{array}$ & $\begin{array}{c}\text { Signifikan/ } \\
\text { Significant }\end{array}$ & $\begin{array}{c}\text { Alfa/ } \\
\text { Alpha }\end{array}$ \\
\hline $\begin{array}{l}\text { Kualitas } \\
\text { produk/Product } \\
\text { quality }\end{array}$ & 0.504 & 8.003 & 0.000 & 0.05 \\
Harga/Price & 0.299 & 4.481 & 0.000 & 0.05 \\
$\begin{array}{l}\text { Citra Merek/ } \\
\text { Brand image }\end{array}$ & 0.225 & 4.176 & 0.000 & 0.05 \\
\hline
\end{tabular}

Berdasarkan Tabel 9 dapat dilihat bahwa kualitas produk, harga dan citra merek memiliki niliai signifikan kurang dari 0,05 yang berarti koefisien regresi signifikan terhadap keputusan pembelian ulang. Adapun bentuk hubungannya dapat dilihat pada Gambar 3 sub struktur II.

Dari hasil analisis jalur sub struktur 1 dan hasil analisis jalur sub struktur 2 diperoleh hasil bahwa kualitas produk $\left(\mathrm{X}_{1}\right)$, harga $\left(\mathrm{X}_{2}\right)$, dan citra merek $\left(\mathrm{X}_{3}\right)$ berpengaruh positif dan signifikan terhadap keputusan pembelian ulang (Y). Hal ini dapat dilihat pada Gambar 4.

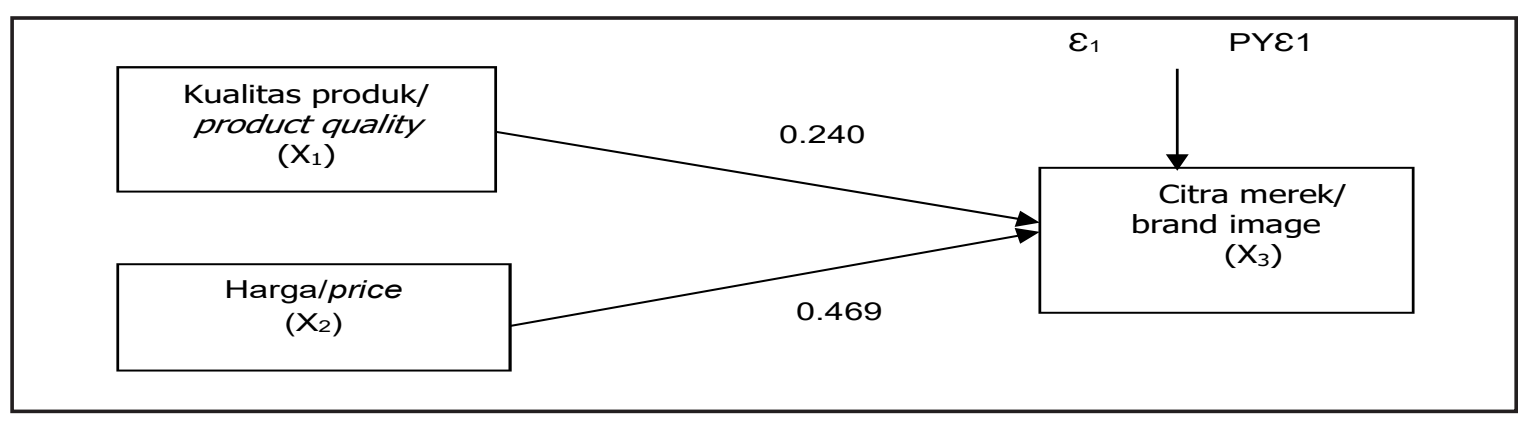

Gambar 2. Koefisien Jalur Pada Sub Struktur 1.

Figure 2. Path Coefficient in Sub-Structure One.

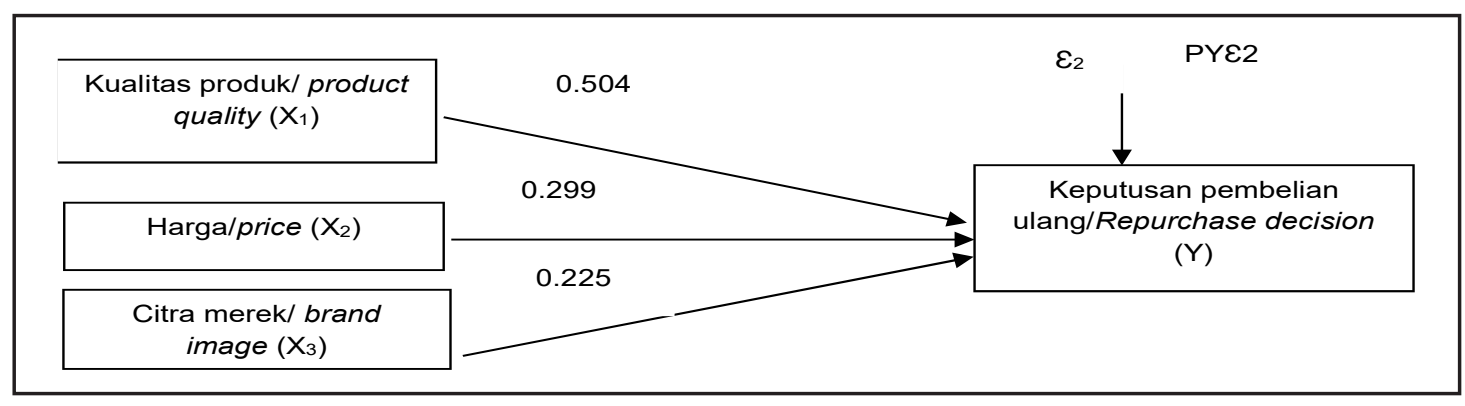

Gambar 3. Koefisien Jalur pada Sub Struktur 2.

Figure 3. Path Coefficient in Sub-Structure Two. 


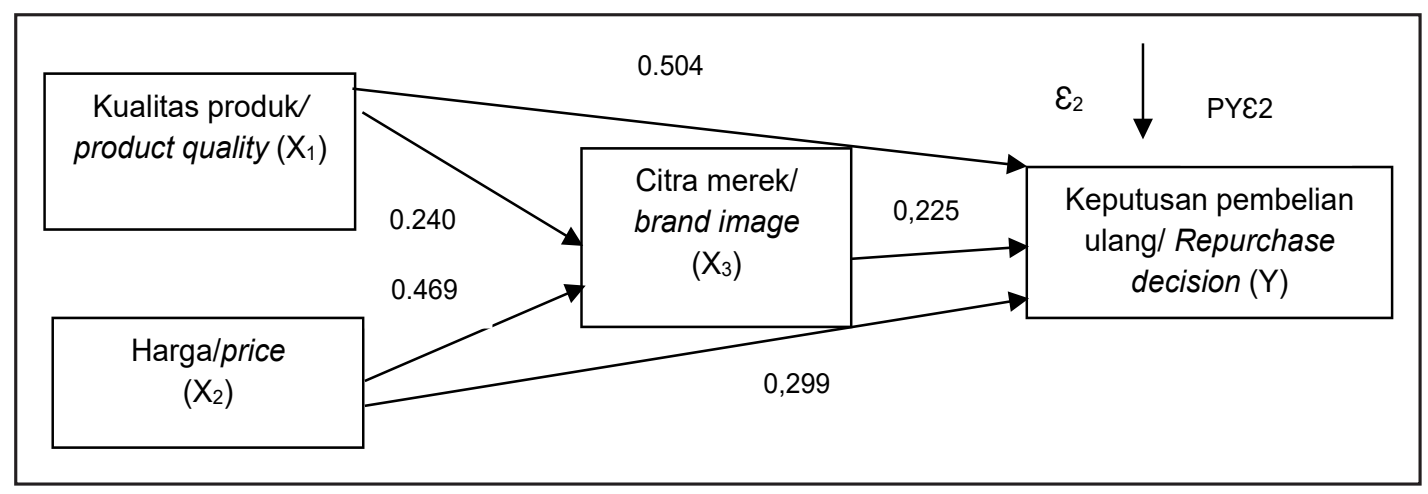

Gambar 4. Struktur Analisis Penelitian.

Figure 4. Structure of Research Analysis.

Berdasarkan analisis data keseluruhan dengan menggunakan analisis jalur maka besarnya kontribusi pengaruh dari variabel penyebab (kualitas produk, harga dan citra merek) terhadap variabel akibat (keputusan pembelian ulang) baik secara langsung maupun tidak langsung dapat dilihat pada Tabel 10 .

\section{A. Pengaruh Kualitas Produk Terhadap Citra Merek}

Berdasarkan hasil analisis koefisien jalur yang terdapat pada Tabel 8 diperoleh pengaruh kualitas produk terhadap citra merek sebesar 0,240. Dan hal ini berarti bahwa kualitas produk

Tabel 10. Rekapitulasi Pengaruh Langsung dan Pengaruh Tidak Langsung Variable Bebas Terhadap Variable Terikat.

Table 10. Recapitulation of Direct and Indirect Effects of Independent Variables towards the Dependent Variable.

\begin{tabular}{|c|c|c|c|c|}
\hline No & $\begin{array}{l}\text { Keterangan/ } \\
\text { linformation }\end{array}$ & $\begin{array}{l}\text { Langsung/ } \\
\text { Direct (\%) }\end{array}$ & $\begin{array}{l}\text { Tidak } \\
\text { Langsung/ } \\
\text { Indirect (\%) }\end{array}$ & $\begin{array}{c}\text { Akumulasi } \\
\text { IAccumulation (\%) }\end{array}$ \\
\hline \multirow[t]{2}{*}{ A } & $\begin{array}{l}\text { Pengaruh kualitas produk }\left(X_{1}\right) \text { terhadap keputusan } \\
\text { pembelian ulang }(Y) / \text { the effect of product quality } \\
\left(X_{1}\right) \text { on repurchase decisions }(Y)\end{array}$ & $25.4 \%$ & & $25.4 \%$ \\
\hline & $\begin{array}{l}\text { Pengaruh kualitas produk }\left(X_{1}\right) \text { terhadap keputusan } \\
\text { pembelian ulang }(Y) \text { melalui citra merek }\left(X_{3}\right) / \\
\text { The effect of product quality }\left(X_{1}\right) \text { on repurchase } \\
\text { decisions }(Y) \text { through brand image }\left(X_{3}\right)\end{array}$ & & $2.7 \%$ & $2.7 \%$ \\
\hline \multicolumn{2}{|r|}{ Total Pengaruh/Total Effects } & $25.4 \%$ & $2.7 \%$ & $28.1 \%$ \\
\hline \multirow[t]{2}{*}{$\mathrm{B}$} & $\begin{array}{l}\text { Pengaruh harga }\left(\mathrm{X}_{2}\right) \text { terhadap keputusan } \\
\text { pembelian ulang }(\mathrm{Y}) / \text { The effect of price }\left(\mathrm{X}_{2}\right) \text { on } \\
\text { repurchase decisions }(\mathrm{Y})\end{array}$ & $8.9 \%$ & & $8.9 \%$ \\
\hline & $\begin{array}{l}\text { Pengaruh harga }\left(X_{2}\right) \text { terhadap keputusan } \\
\text { pembelian ulang }(Y) \text { melalui citra merek }\left(X_{3}\right) \text { ) } \\
\text { The effect of price }\left(X_{2}\right) \text { on repurchase decisions }(Y) \\
\text { through brand image }\left(X_{3}\right)\end{array}$ & & $3.2 \%$ & $3.2 \%$ \\
\hline \multicolumn{2}{|r|}{ Total Pengaruh/Total Effects } & $8.9 \%$ & $3.2 \%$ & $12.1 \%$ \\
\hline C & $\begin{array}{l}\text { Pengaruh citra merek }\left(\mathrm{X}_{3}\right) \text { terhadap keputusan } \\
\text { pembelian ulang }(\mathrm{Y}) / \text { The effect of brand image }\left(X_{3}\right) \\
\text { on repurchase decisions }(Y)\end{array}$ & 5.1 & & $5.1 \%$ \\
\hline \multicolumn{2}{|c|}{$\begin{array}{l}\text { Total Pengaruh Model Penelitian/The total effect of } \\
\text { research model }\end{array}$} & $39.4 \%$ & $5.9 \%$ & $45.3 \%$ \\
\hline \multicolumn{2}{|c|}{ Pengaruh variabel lain/The effect of other models } & & & $54.7 \%$ \\
\hline \multicolumn{2}{|c|}{ Total pengaruh keseluruhan/Total overall effect } & & & $100 \%$ \\
\hline
\end{tabular}


memiliki pengaruh positif dan signifikan terhadap citra merek. Artinya, semakin bagus kualitas produk ikan asin di Kota Padang maka semakin tinggi pula citra merek yang dimiliki oleh ikan asin di Kota Padang. Penelitian ini sejalan dengan penelitian yang dilakukan oleh Sundalangi, Mandey \& Jorie (2014) menunjukkan bahwa secara simultan kualitas produk, daya tarik iklan dan potongan harga berpengaruh terhadap keputusan pembelian konsumen dengan nilai yang signifikan. Selanjutnya hal yang sama juga ditemukan pada penelitian yang dilakukan oleh Heriyati \& Septi. (2012), Nurdianto \& Yuniati (2013) serta penelitian yang dilakukan oleh Nuraini \& Maftukhah (2015) menyimpulkan bahwa variabel kualitas produk berpengaruh terhadap brand image yang dapat mempengaruhi konsumen dalam membeli sebuah produk. Situmorong, L., I. (2017) di dalam penelitiannya menemukan bahwa kualitas produk memberikan pengaruh yang positif dan signifikan terhadap citra merek, yaitu apabila suatu produk memiliki kualitas yang baik maka citra merek produk tersebut di mata konsumen akan ikut baik.

Oleh sebab itu semakin majunya perkembangan IPTEK maka kualitas produkmenjadi sebuah variabel penting yang mempengaruhi citra merek dari sebuah produk. Hendro \& Hidayat. (2018) mengatakan bahwa di era modern saat ini membuat perusahaan bisnis berlomba-lomba untuk memproduksi produk-produk yang memiliki kualitas yang terbaik dengan keunikan dan perbedaan yang unggul dari pesaingnya. Hal ini sejalan dengan pendapat yang dikemukakan oleh Kotler \& Keller (2012) mengatakan bahwa apabila sebuah perusahaan ingin mempertahankan keunggulan kompetitif dalam pasar maka harus mengerti aspek dimensi apa saja yang digunakan konsumen untuk membedakan produk yang dijual perusahan tersebut dengan produk pesaing.

\section{B. Pengaruh Harga Terhadap Citra Merek}

Berdasarkan hasil analisis koefisien jalur sebesar 0,469 yang terdapat pada tabel 8 maka hal ini berarti bahwa harga memiliki pengaruh positif dan signifikan terhadap citra merek. Artinya, semakin layak harga ikan asin di Kota Padang maka semakin tinggi pula citra merek yang dimiliki oleh ikan asin. Hasil penelitian yang diperoleh dilapangan di dukung oleh penelitian yang dilakukan oleh Afrian \& Sutopo (2017) menemukan hasil penelitian yang menunjukkan bahwa harga berpengaruh positif terhadap citra merek.
Hasil yang diperoleh mengisyaratkan bahwa harga atau pengorbanan yang dikeluarkan konsumen akan semakin tinggi ketika produk yang dibeli memiliki citra merek yang tinggi. Selanjutnya hasil penelitian ini sesuai dengan penelitian yang dilakukan oleh Dahmiri (2009) dan Noerchoidah (2013) menyimpulkan bahwa variabel harga berpengaruh secara signifikan terhadap citra merek (brand image). Hal ini juga di dukung oleh penelitian yang dilakukan Amanah (2011) mengemukakan apabila citra merek (brand image) konsumen meningkat maka loyalitas pembelian akan ikut meningkat dan konsumen akan mampu memberikan harga yang cukup tinggi terhadap suatu produk apabila produk yang dibeli memiliki citra yang tinggi.

Oleh sebab itu seorang produsen maupun pedagang sebagai perantara antara produsen dengan konsumen harus mampu menetapkan harga dengan citra merek yang terkandung pada produk tersebut. Karena penetapan harga terlalu murah atau terlalu mahal akan membentuk citra merek tersendiri dalam ingatan konsumen. Dilihat dari sudut pandang konsumen harga seringkali dihubungkan dengan manfaat yang dirasakan atas suatu barang atau jasa tersebut. Hal ini sesuai dengan pendapat yang dikemukakan oleh Tjiptono (2015) yang menemukan bahwa harga merupakan satuan moneter atau ukuran lainnya yang dapat ditukarkan agar memperoleh hak kepemilikan atau penggunaan suatu barang atau jasa. Kesan positif sebuah produk yang dirasakan oleh seorang konsumen akan mendorong meningkatnya nilai produk tersebut yang terlihat dari harga jual produk tersebut.

\section{Pengaruh Kualitas Produk Terhadap Keputusan Pembelian Ulang}

Berdasarkan hasil analisis koefisien jalur sebesar 0,504 yang terdapat pada Tabel 9 maka hal ini berarti bahwa kualitas produk memiliki pengaruh positif dan signifikan terhadap keputusan pembelian ulang. Artinya, semakin bagus kualitas produk ikan asin maka semakin tinggi pula keputusan pembelian ulang yang dimiliki oleh ikan asin di kota padang. Hasil penelitian ini dapat dilihat dari respon yang diberikan oleh responden dalam pengisian kuesioner yang telah teruji tingkat validitas dan reabilitanya, dimana meningkatnya keputusan pembelian ulang sebagai akibat dari pengaruh kualitas produk disebabkan oleh tiga indikator penting, yaitu (a) daya tahan produk, (b) kualitas yang dirasakan dan (c) keindahan tampilan. 
Hasil penelitian ini sesuai dengan penelitian yang dilakukan oleh Arianto \& Albani (2018) dan penelitian Mulyani, Zahara \& Santi (2015) menyimpulkan bahwa kualitas produk berpengaruh secara signifikan terhadap keputusan pembelian konsumen. Lebih lanjut Mulyani et al.(2015) mengemukakan bahwa keputusan pembelian ulang tercipta karena adanya minat beli ulang konsumen pada produk lipstick merek wardah.

Penelitian ini juga di dukung oleh penelitian yang dilakukan oleh Nicholas \& Keni (2018) yang melakukan penelitian pada kualitas dari design sebuah website, dari penelitian tersebut di peroleh hasil bahwa kualitas dari sebuah design website secara positif mempengaruhi keputusan pembelian konsumen (repurchase intention). Hal ini berarti semakin baik kualitas dari sebuah produk yang diberikan kepada konsumen maka hal tersebut akan menyebabkan konsumen untuk melakukan pembelian atas produk tersebut.

\section{Pengaruh Harga terhadap Keputusan Pembelian Ulang}

Berdasarkan hasil analisis koefisien jalur sebesar 0,299 yang terdapat pada tabel 9 maka hal ini berarti bahwa harga memiliki pengaruh positif dan signifikan terhadap keputusan pembelian ulang. Artinya, semakin layak harga ikan asin di Kota Padang maka semakin tinggi pula keputusan pembelian berulang konsumen ikan asin di Kota Padang. Hasil penelitian ini dapat dilihat dari respon yang diberikan oleh responden dalam pengisian kuesioner yang telah teruji tingkat validitas dan reabilitanya, dimana menguatnya citra merek ikan asin sebagai akibat dari pengaruh harga disebabkan oleh tiga indikator penting, yaitu (a) keterjangkauan harga oleh konsumen, (b) daya saing harga dan (c) kesesuaian harga dengan manfaat produk.

Hasil penelitian ini sesuai dengan penelitian yang dilakukan Arianto \& Albani (2018) yang menyimpulkan bahwa harga berpengaruh secara signifikan terhadap keputusan pembelian konsumen. Selanjutnya penelitian tersebut juga didukung oleh penelitian yang dilakukan oleh Adawiah \& Bahri (2015) bahwa harga berpengaruh terhadap loyalitas pelanggan yang mampu mempengaruhi konsumen untuk melakukan pembelian berulang. Selanjutnya Widjaja \& Sudarsono. (2015) membuktikan bahwa keputusan pembelian ulang konsumen atas produk air mineral AQUA sebagian besar dipengaruhi oleh kualitas produk dan harga karena harga merupakan salah satu unsur bauran pemasaran (marketing mix) yang mampu memberikan pendapatan pada sebuah perusahaan.

\section{E. Pengaruh Citra Merek Terhadap Keputusan Pembelian Ulang}

Berdasarkan hasil analisis koefisien jalur sebesar 0,225 yang terdapat pada Tabel 9 maka hal ini berarti citra merek memiliki pengaruh positif dan signifikan terhadap keputusan pembelian berulang konsumen. Artinya, semakin bagus citra merek ikan asin tersebut dimata konsumen maka akan berdampak positif terhadap pembelian berulang yang dilakukan oleh konsumen. Hasil penelitian ini dapat dilihat dari respon yang diberikan oleh responden dalam pengisian kuesioner yang telah teruji tingkat validitas dan reabilitanya, dimana menguatnya keputusan pembelian berulang sebagai akibat dari pengaruh citra merek disebabkan oleh tiga indikator penting, yaitu (a) atribut, (b) nilai (c) kepribadian konsumen.

Hasil penelitian ini sesuai dengan hasil penelitian yang dilakukan oleh Kurniawan, Arifin \& Fanani (2018) yang memperoleh hasil bahwa secara parsial citra produk merupakan variabel yang berpengaruh signifikan terhadap keputusan pembelian laptop ber merek ASUS. Selanjutnya penelitian yang dilakukan oleh Nurfadila \& Asriadi (2015) menyimpulkan bahwa citra merek dan kepercayaan merek berpengaruh secara signifikan terhadap keputusan pelanggan dalam membeli sebuah produk dan hal tersebut akan berdampak terhadap loyalitas merek ataupun loyalitas sebuah perusahaan. Mutmainnah (2017) dalam penelitiannya menyimpulkan bahwa citra perusahaan salah satunya terbentuk dari citra merek yang akan menyebabkan konsumen untuk loyal terhadap perusahaan. Oleh sebab itu, konsumen yang telah memiliki loyalitas terhadap suatu merek akan menyebabkan konsumen tersebut untuk melakukan pembelian secara berulang.

\section{F. Hubungan antara Kualitas Produk, Harga dan Citra Merek terhadap Keputusan Pembelian Berulang}

Produk yang berkualitas merupakan produk yang dapat memberikan nilai dan manfaat kepada konsumen yang menggunakannya. Banyak konsumen yang beranggapan bahwa semakin kompetitif harga yang ditawarkan atas suatu produk, maka hal tersebut dapat mendorong 
konsumen dalam membeli ulang produk tersebut. Dari hasil penelitian yang dilakukan oleh Sondakh (2014) menemukan bahwa kualitas dan citra merek memiliki pengaruh terhadap kepuasan konsumen dan berdampak terhadap loyalitas nasabah (konsumen) tersebut.

Berdasarkan hal tersebut maka ketika kualitas produk dapat memberikan nilai dan manfaat yang diharapkan konsumen secara konsisten maka hal ini akan menciptakan citra merek atau brand image tersendiri dalam diri konsumen terhadap produk yang bersangkutan. Oleh sebab itu salah satu upaya peningkatan brand image ikan asin tersebut dapat dilakukan dengan upaya pemanfaatan peran perumpuan dalam proses pengolahan hasil perikanan Nurlaili \& Muhartono (2017) menemukan bahwa perempuan memiliki peran yang strategis dalam tiap tahapan kegiatan usaha perikanan dan sebagai titik tumpu dalam program pembangunan. Oleh sebab itu konsumen ikan asin yang sebagian besar adalah perempuan dan di dukung dengan mengikutsertakan perempuan dalam proses pemasaran ikan asin maka hal tersebut akan mampu nmemberikan pengaruh positif terhadap loyalitas konsumen.

Hal ini sesuai dengan penelitian yang dilakukan oleh Amanah (2011) tentang loyalitas pemebelian produk pepsodent di ramayana plaza Kota Medan yang menunjukkan bahwa apabila brand image konsumen meningkat maka loyalitas pembelian akan ikut meningkat. Selanjutnya jika dilihat pada faktor harga, dimana harga berpengaruh positif terhadap citra merek (brand image) karena konsumen akan mampu memberikan harga yang cukup tinggi terhadap suatu produk apabila produk yang dibeli memiliki citra atau brand image yang tinggi.

\section{KESIMPULAN DAN REKOMENDASI KEBIJAKAN}

\section{Kesimpulan}

Kualitas produk, harga dan citra merek berpengaruh signifikan terhadap keputusan pembelian ulang ikan asin di Kota Padang. Produk yang memiliki kualitas yang baik dan di dukung dengan harga jual yang sesuai dengan nilia atau manfaat yang diperoleh oleh konsumen maka hal tersebut akan meningkatkan jumlah pembelian berulang yang dilakukan oleh konsumen. Yaitu: (a) kualitas produk berpengaruh signifikan terhadap citra merek sebesar 0,240 . (b) harga berpengaruh signifikan terhadap citra merek sebesar 0,469 . (c) kualitas produk berpengaruh signifikan terhadap keputusan pembelian ulang sebesar 0,504. (d) harga berpengaruh signifikan terhadap keputusan pembelian ulang sebesar 0,299. (e) citra merek berpengaruh signifikan terhadap keputusan pembelian ulang sebesar 0,225.

\section{Rekomendasi Kebijakan}

Sehubungan dengan penelitian yang penulis lakukan dengan melihat pengaruh langsung dan tidak langsung kualitas produk, harga dan citra merek terhadap pembelian berulang maka seorang produsen atau pedagang ikan asin di Kota Padang agar selalu berusaha untuk mempertahankan keunggulan yang sudah ada dan berupaya meminimalkan kelemahan dan tantangan yang dihadapi sehingga konsumen selalu memlakuakn pembelian yang berulang pada produk ikan asin.

Berdasarkan hal tersebut, maka dengan melakukan perbaikan pada aspek, kualitas produk, harga dan citra mereknya maka hal tersebut akan berdampak terhadap konsumen ikan asin di Kota Padang yang semakin meningkat dari tahun ketahun. Hal ini dapat dilihat dari pengaruh kualitas produk secara langsung dan tidak langsung terhadap keputusan pembelian ulang, yaitu secara langsung sebesar $25,4 \%$ dan tidak langsung sebesar $2,7 \%$ Perlindungan konsumen yang di berikan oleh pemerintah dapat terealisasi secara optimal. Akibatnya konsumen memiliki tingkat kepercayaan untuk mengkonsumsi ikan asin. Dan untuk penelitian selanjutnya direkomendasikan agar melakukan penelitian yang lebih mendalam dengan menambahkan faktor lainnya seperti lokasi dan pelayanan serta dilakukannya pengembangan pada objek penelitian yang tidak hanya pada bidang produk namun juga pada bidang jasa.

\section{UCAPAN TERIMAKASIH}

Tulisan ini merupakan hasil temuan lapangan dari sebuah kajian tentang Pengaruh Kualitas Produk, Harga dan Citra Merek terhadap Keputusan Pembelian Ulang Ikan Asin di Kota Padang. Untuk itu ucapan terimakasih, kami tujukan kepada Direktorat Riset dan Pengabdian Masyarakat. Direktorat Jenderal Penguatan Riset dan Pengembangan. Kementerian Riset, Teknologi, dan Pendidikan Tinggi. Sesuai dengan Kontrak Penelitian. Nomor: 007/L10/AK.04/KONTRAKPENELITIAN/2019 yang telah bersedia membiayai 
penelitian ini serta Universitas Nahdlatul Ulama Sumatera Barat yang telah memfasilitasi kami untuk dapat bertemu dengan informan yang berasal dari berbagai kecamatan yang ada di Kota Padang. Terima kasih juga kami sampaikan kepada para informan yang telah bersedia memberikan informasi sehingga menjadi data yang sangat berharga bagi tulisan ini. Selanjutnya akhir kata, kami sampaikan terima kasih kepada para reviewer yang telah memberikan masukan yang berharga di dalam penyempurnaan tulisan ini.

\section{PERNYATAAN KONTRIBUSI PENULIS}

Dengan ini kami menyatakan bahwa kontribusi masing-masing penulis terhadap pembuatan karya tulis adalah: Imtihan sebagai kontributor utama dan Irwandi sebagai anggota. Penulis menyatakan bahwa telah melampirkan surat pernyataan kontribusi penulis.

\section{DAFTAR PUSTAKA}

Adawiah, R \& Bahri, S. (2015). Pengaruh Persepsi Harga dan Citra Merek terhadap Loyalitas Pelanggan Menggunakan Produk Kosmetik (Studi pada Swalayan Grand Hero di Kota Palu). Jurnal IImu Manajemen Universitas Tadulako. Vol.1(3), 271 - 278. Retrieved from https://jimutuntad.com/index.php/jimut/article/ view/28/28

Afrian, R \& Sutopo. (2017). Analisis Pengaruh Adanya Factor Harga, Kualitas Produk Dan Citra Merek Terhadap Keputusan Pembelian (Studi Kasus Pada UD. Ikan Mas Di Kabupaten Pemalang). Diponegoro Journal Of Management. Vol.6(4), 1-11. Retrieved from https://ejournal3.undip. ac.id/index.php/djom/article/view/18038

Amanah, D. (2011). Pengaruh Promosi dan Brand Amage (Citra Produk) terhadap Loyalitas Pembelian Produk Pepsodent di Ramayana Plaza, Jalan Aksara Medan. Jurnal Keuangan dan Bisnis. Vol 3(3), 221 - 233. doi: 10.17605/ OSF.IO/AX5V3

Arianto, N \& Albani, A. F. (2018). Pengaruh Kualitas Produk dan Harga terhadap Keputusan Pembelian Smarphone Pada Samsung Store Mall Bintaro Exchange. Jurnal IImiah Manajemen Forkamma. Vol 1(3), 1-14. doi: http://dx.doi.org/10.32493/ frkm.v1i3.2545

Dahmiri. (2009). Pengaruh Bauran Penjualan Eceran (Retailing Mix) terhadap Citra Department Store (Studi pada Ramayana Department Store Kota Jambi). Jurnal Manajemen Pemasaran Modern. Vol.1(1), 2085-0972. Retrieved from https:// online-journal.unja.ac.id/pemasaran/article/ view/497
Hendro, C. R \& Hidayat. W. (2018). Pengaruh Kualitas Produk, Harga dan Citra Merek terhadap Keputusan Pembelian Konsumen Handphone Merek Iphone Kota Semarang. Jurnal IImu Administrasi Bisnis, 7(4), 177-184. Retrieved from https://ejournal3.undip.ac.id/index.php/jiab/ article/view/21932

Heriyati, P \& Septi. (2012). Analisis Pengaruh Brand Image dan Kualitas Produk Terhadap Keputusan Pembelian Konsumen pada Handphone Nexian. Journal Of Business Strategy and Execution. Vol.4(2), 171 - 205. Retrieved from https://journal. binus.ac.id/index.php/JBSE/article/view/275

Idris. (2012). Aplikasi Analisis Data Kuantitatif dengan Program SPSS. Padang, ID: UNP.

Kotler, P. \& Keller, K.L. (2012). Marketing Management Edisi 13. New Jersey. Jakarta: Erlangga.

Kurniawan, F., Arifin, F., \& Fanani, D. (2018). Pengaruh Citra Merek terhadap Keputusan Pembelian (Survei Kepada Para Siswa SMAN 15 Surabaya Kelas XII Yang Menggunakan Laptop Ber Merek ASUS). Jurnal Administrasi Bisnis (JAB) Vol: 56(1),75-81.Retrieved from http://administrasibisnis.studentjournal.ub.ac.id/index.php/jab/ article/view/2319

Mulyani, Zahara, Z \& Santi, I., N. (2015). Pengaruh Kualitas Produk terhadap Minat Beli Ulang Lipstik Merek Wardah pada Mahasiswi Universitas Tadulako Palu. Jurnal IImu Manajemen Universitas Tadulako. Vol.1(3), 279 - 286. Doi: https://doi. org/10.22487/jimut.v1i3.29

Mutmainnah. (2017). Pengaruh Kualitas Layanan dan Citra Perusahaan terhadap Kepuasan dan Loyalitas Nasabah. Jurnal Manajemen dan Pemasaran Jasa. Vol.10(2), 201-216. Doi:10.25105/jmpj.v10i2.2344

Nicholas, W \& Keni. (2018). Pengaruh Website Design Quality dan Kualitas Jasa terhadap Repurchase Intention: Variabel Trust Sebagai Variabel Mediasi. Jurnal Manajemen dan Pemasaran. Vol.11(2), 291-310. Retrieved from https://trijurnal.lemlit. trisakti.ac.id/jasa/article/view/3006

Noerchoidah. (2013). Analisis Pengaruh Harga, Kualitas Produk dan Iklan terhadap Brand Image dan Keputusan Pembelian Sepeda Motor Merek Kawasaki. Jurnal WIGA Jurnal Penelitian IImu Ekonomi. Vol.3(1), 2088-0944. https://doi. org/10.30741/wiga.v3i1.88

Nuraini, A \& Maftukhah, I. (2015). Pengaruh Celebrity Endorser dan Kualitas Produk terhadap Keputusan Pembelian melalui Citra Merek pada Kosmetik Wardah di Kota Semarang. Management Analysis Journal, Vol.4(2), 2252-6552. Doi: 10.15294/maj. v4i2.7839

Nurdianto, D \& Yuniati, T. (2013). Pengaruh Kualitas Produk dan Citra Merek sebagai Variabel 
Intervening terhadap Keputusan Konsumen dalam Membeli Motor Honda. Jurnal IImiah Dan Riset Manajemen. Vol.2(10), 1-29. Retrieved from https://adoc.pub/pengaruh-kualitas-produk-dan-citra-sebagai-variabel-interven.html

Nurfadila, M.,S \& Asriadi (2015). Pengaruh Citra Merek dan Kepercayaan Merek terhadap Kepuasan Pelanggan Serta Dampaknya terhadap Loyalitas Merek Sepeda Motor Merek Honda. Jurnal IImu Manajemen Universitas Tadulako. Vol.1(3), 319 - 332.doi: https://doi.org/10.22487/jimut. v113.33

Nurlaili \& Muhartono, R. (2017). Peran Perempuan Nelayan dalam Usaha Perikanan Tangkap dan Peningkatan Ekonomi Rumah Tangga Pesisir Teluk Jakarta. Jurnal Sosial Ekonomi Kelautan dan Perikanan. Vol.12(2), 203-212. Doi: http:// dx.doi.org/10.15578/jsekp.v12i2.6481

Pemerintah Republik Indonesia. (1999). Undang-Undang Nomor 8 Tahun 1999 tentang Perlindungan Konsumen. Jakarta, ID: Pemerintah Republik Indonesia

Safaruddin. (2018). Ikan Asin Produk Andalan Warga Pasia Jambak. Retrieved from https://www.harianhaluan.com/news/ detail/70544/ikan-asin-produk-andalan-warga-pasia-jambak

Situmorong, L., I. (2017). Pengaruh Kualitas Produk dan Iklan terhadap Citra Merek dan Keputusan Pembelian Produk Kecantikan Merek Pond's Pada Remaja Di Kota Pekanbaru. Jurnal JOM Fekon. Vol 4(1), 72-86. Retrieved from https:// jom.unri.ac.id/index.php/JOMFEKON/article/ view/12298/11943

Sondakh, C. (2014). Kualitas Layanan, Citra Merek dan Pengaruhnya terhadap Kepuasan Nasabah dan Loyalitas Nasabah Tabungan (Studi pada Nasabah Taplus BNI Cabang Manado). Jurnal Riset Bisnis dan Manajemen. Vol 3(1),19-32. Retrieved from https://ejournal.unsrat.ac.id/ index.php/jrbm/article/view/7525

Sundalangi, M., Mandey, S., L \& Jorie, R., J. (2014). Kualitas Produk, Daya Tarik Iklan dan Potongan Harga terhadap Minat Beli Konsumen pada Pizza Hut Manado. Jurnal EMBA: Jurnal Riset Ekonomi, Manajemen, Bisnis dan Akuntansi. Vol 2(1), 313 - 324. Doi : https://doi.org/10.35794/ emba.v2i1.3829

Tjiptono, F. (2015). Strategi Pemasaran. Yogyakarta, ID: Penerbit Andi Offset

Widjaja, M., A., \& Sudarsono.(2015). Pengaruh Kualitas Produk dan Harga Pada Kepercayaan Merek Dan Efeknya Terhadap Keputusan Pembelian Ulang Konsumen Produk Air Mineral Aqua. Jurnal Ekonomi Manajemen. Vol 1. Retrieved from http://e-journal.uajy.ac.id/6731/1/JURNAL. pdf
Yusra . (2017). Analisis Kandungan Formalin Ikan Asin Kering di Gasan Gadang, Kabupaten Padang Pariaman, Sumatera Barat. Jurnal Katalisator Kopertis Wilayah X. Vol(1), 20-28. http://ejournal. kopertis10.or.id/index.php/Katalisator.

Yusra \& Y. Efendi.2010. Dasar-dasar Teknologi Hasil Perikanan. Penerbit Bung Hatta University Press. Padang. 